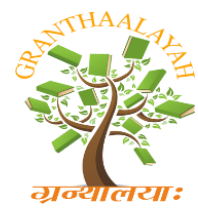

INTERNATIONAL JOURNAL OF RESEARCH GRANTHAALAYAH

A knowledge Repository

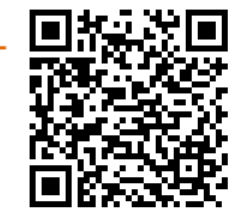

Social

\title{
A STUDY ON RELATION BETWEEN STUDY HABITS AND PERSONALITY TRAITS OF HIGHER SECONDARY STUDENTS
}

\author{
K.Nuvetha Sheebha ${ }^{* 1}$ \\ ${ }^{* 1}$ Research Scholar, Bharathiar University, Coimbatore, INDIA \\ ${ }^{* 1}$ Assistant Professor, CMS College of Education, Coimbatore, INDIA
}

\begin{abstract}
Acquiring five years of general education, at the higher secondary level, the students are focused to a diversification of subjects. Hence, they automatically develop into students following certain new study habits, which suit their change in the academic field. Many students undergo private tuition to improve their performance, but this improvement cannot be achieved overnight. What they need is improvement in studies by various ways and means. This can be achieved only by means of having proper and regular study habits.
\end{abstract}

Keywords:

Students, Study Habits, Personality Traits.

Cite This Article: K.Nuvetha Sheebha, "A STUDY ON RELATION BETWEEN STUDY HABITS AND PERSONALITY TRAITS OF HIGHER SECONDARY STUDENTS" International Journal of Research - Granthaalayah, Vol. 4, No. 5: SE (2016): 40-43.

\section{INTRODUCTION}

An important objective of education throughout the world today is the promotion of international understanding among the people of the world. Through education people are made to get-rid of superstitious beliefs and develop a scientific outlook on life. The prosperity of a nation depends very much upon the educational system of that country as it prepares the future citizens of the country and plays major roles in various walks of life. Education broadens horizons, improves one's skills, develops the ability to plan and implement programs. Education is a process through which knowledge is gained, skills are developed, attitudes are modified and behavior patterns and values are evolved. It is not a onetime process. It is, and it has to be there throughout one's life. We designate it as lifelong education. It can be formal, non-formal, or informal or a combination of all these. Education should aim at liberation. Proper Education is the only panacea for all the evils of the society. The development of good study habits is the highway to the goals of an individual, whatever they are. A simple, small change in study habits makes a big difference in goal setting and organization of one's life. The success of an individual depends upon his study habits. Education is the manifestation of perfection already 
existing in man. The tool enabling this manifestation is study habits. Learning how to study is really a long-term process.

\section{NEED FOR THE STUDY}

The teaching-learning process involves a simultaneous mutual exchange of ideas and interaction between the teachers and the taught where besides the teacher, the learner has to organize himself for work, to do the assigned work, to solve problems and to make decisions which reveal something about his unique study habits. There are major differences in the study habits from one student to another and those differences can have a significant bearing on the totality of learning. Unless a teacher can pinpoint exactly 'What' a child needs to study and 'how' he could develop the study habits to establish a most successful pattern of studying, any attempt on individualized instruction is like a shot in the dark.

Students' needs, requirements, abilities, capabilities, their pattern of studying etc. have been neglected for a long time and they were forced to learn the same thing, by the same method, by the same person in the same environment.

\section{OBJECTIVES}

- To find the level of study habits of higher secondary students.

- To find the level of study habits of higher secondary students with regard to background variable; gender, religion, community, type of school, nature of school, family type and birth order.

- To find the level of personality traits - self-concept, temperament, adjustment and anxiety of higher secondary students.

\section{HYPOTHESES OF THE STUDY}

- The higher secondary students are not having good study habits

- There is no significant difference between male and female higher secondary students in their academic achievement.

- There is no significant difference between Hindu and non-Hindu higher secondary students in their academic achievement.

\section{METHODOLOGY}

For analyzing the study habits of higher secondary students in relation to their personality traits, the investigator has used survey method of research for her study. Survey research deals with incidence, distribution and relationship of educational, psychological and sociological variables.

\section{SAMPLE}

From the population, the investigator has taken 217 higher secondary students by using stratified random sampling method. 


\section{TOOLS USED}

- A Bio-Data Form.

- Study Habits Inventory developed by B.V. Patel.

- Manjurani Agarwal's Multi-dimensional Personality Inventory.

\section{STASTISTICAL TECHNIQUES USED}

In the present study, the following statistical techniques were used are: Mean, Standard Deviation, 't' Test, ANOVA, Chi-square test, and Pearson's Product Moment Correlation.

\section{ANALYSIS AND INTERPRETATION OF DATA}

Hypothesis 1: The higher secondary students are not having good study habits.

Table 1: Level of Study Habits of Higher Secondary Students

\begin{tabular}{|l|l|l|l|l|}
\hline \multirow{2}{*}{ Variable } & \multicolumn{3}{|l|}{ Poor } & Good \\
\cline { 2 - 5 } & $\mathrm{N}$ & $\%$ & $\mathrm{~N}$ & $\%$ \\
\hline Study Habits & 121 & 55.76 & 96 & 44.24 \\
\hline
\end{tabular}

It is inferred from the above table that the higher secondary students have poor study habits. Hence, the null hypothesis is accepted.

Hypothesis 2: There is no significant difference between male and female higher secondary students in their academic achievement.

Table 2: Difference in Academic Achievement of Higher Secondary Students with regard to Gender

\begin{tabular}{|l|l|l|l|l|l|l|}
\hline Gender & $\mathrm{N}$ & Mean & SD & $\begin{array}{l}\text { Calculated } \\
\text { 't' Value }\end{array}$ & $\begin{array}{l}\text { Table } \\
\text { Value }\end{array}$ & Remark \\
\hline Male & 100 & 596.00 & 126.39 & 4.80 & 1.96 & $\mathrm{~S}$ \\
\hline Female & 117 & 684.09 & 144.01 & 40 & \\
\hline
\end{tabular}

$(\mathrm{df}=215)$

$\mathrm{S}=$ Significant at 5\% Level : Null Hypothesis is Rejected.

Hypothesis 3: There is no significant difference between Hindu and non-Hindu higher secondary students in their academic achievement.

Table 3: Difference in Academic Achievement of Higher Secondary Students with regard to Religion

\begin{tabular}{|l|l|l|l|l|l|l|}
\hline Religion & $\mathrm{N}$ & Mean & SD & $\begin{array}{l}\text { Calculated } \\
\text { 't' Value }\end{array}$ & $\begin{array}{l}\text { Table } \\
\text { Value }\end{array}$ & Remark \\
\hline Hindu & 197 & 640.58 & 144.63 & 1.07 & 1.96 & NS \\
\hline
\end{tabular}




\begin{tabular}{l|l|l|l|l|l|l|}
\hline Non-Hindu & 20 & 672.15 & 123.09 & & & \\
$(\mathrm{df}=215)$ & $=$
\end{tabular}
NS

\section{FINDINGS}

- From the percentage analysis, $55.76 \%$ of higher secondary students have poor study habits and $44.24 \%$ of them have good study habits.

- No significant difference is found between the male and female higher secondary students in their self-concept, temperament and adjustment. Significant difference is found between them in their anxiety. Female students have high anxiety than the male students.

- No significant difference is found between the Hindu and non-Hindu students in their self-concept, temperament, adjustment and anxiety.

\section{CONCLUSION}

The higher secondary students studying in government and private schools may be given proper motivation to develop their study habits. In order to motivate, the students should be offered a bridge course or a small orientation program about the study habits and personality development. Students may be trained on time budgeting and planning for learning the subjects. Due to better time budgeting, the students may make themselves engaged in all the co-curricular activities and extracurricular activities. Participation of these programs may create enthusiasm among the students and create interest over the study.

\section{REFERENCES}

[1] Philip. G. Zimbardo and Richard J. Garring (1999) Psychology - World Color, The Lehigh Press, Pennsauken, NJ, United States, P. 403.

[2] Aggarwal, J.C. (1996) Essentials of Educational Psychology, Vikas Publishing Pvt. Ltd., New Delhi P. 179.

[3] Chaube, S.P. (1999) Educational Psychology and Educational Statistics, Lakshmi Narain Agarwal, Agra Educational Publishers, New Delhi, P. 78.

[4] Patel, M.R. (1997) "Study Habits of Pupils and Its Impact upon Their Academic Achievement", The Progress of Education, Pune Vidyarthi Griha Prakashan, Vol. LXXI, No. 6, January 1997, P. 74.

[5] Gelat, V.K. (1997) “A Study of the Effect of Study Habits on Educational Achievement of the Students of Secondary Schools”, The Progress of Education, Pune Vidyarthi Griha Prakashan, Vol. LXXI, No. 6, January 1997, P. 205.

[6] Golden, S. A. R. (2011). Problems and Prospectus of Distance Learning, Bharathidhasan University, 343- 344.

[7] Ron Fry (2000) How to Study, 5th Ed., Career Press, Franklin Lakes, N.J., P. 15.

[8] Jamuar, K.K. (1974) Study Habits of College Students, Indian International Publications, Allahabad, Pp. 3 - 4. 